\section{Evaluation of Cultivars and Spray Programs for Organic Grape Production in Virginia}

\author{
Laban K. Rutto ${ }^{1}$, Zelalem Mersha ${ }^{1}$, and Mizuho Nita ${ }^{2}$
}

\begin{abstract}
ADDITIONAL INDEX wORDs. black rot, downy mildew, organic viticulture, phomopsis, season

SuMmary. The French American hybrid grape cultivars Corot noir and Arandell (Vitis sp.), and Vidal blanc and Petit Manseng (Vitis vinifera), along with different spray programs, were evaluated for potential organic production in Virginia from 2013 to 2014 . Results obtained in the study demonstrate that organic wine grape production in Virginia can be achieved by using select grape cultivars and spray programs. With the exception of Vidal blanc, disease severity and disease incidence were below the threshold for maintaining healthy vines in all organically managed grape cultivars. 'Vidal blanc' was not sufficiently resistant to downy mildew (Plasmopara viticola), precluding it from potential organic management in Virginia. The study also demonstrated significant disease resistance in Virginia of the cultivar Arandell, released by Cornell University (Ithaca, NY) in 2013. The results suggest that the organically registered fungicide Bacillus subtilis is effective in reducing the severity and incidence of black rot (Guignardia bidwellii) and phomopsis cane and leaf spot (Phomopsis viticola). The chemistry of organically managed berries harvested in 2014 met minimum requirements for wine production with soluble solids, titratable acidity, and $\mathrm{pH}$ ranging from $18.7 \%$ to $20.2 \%, 7.6$ to $8.0 \mathrm{~g} \cdot \mathrm{L}^{-1}$, and 3.3 to 3.4 , respectively, in 'Arandell' and 'Corot noir'; and $21.0 \%$ to $24.4 \%, 7.8$ to 9.6 $\mathrm{g} \cdot \mathrm{L}^{-1}$, and 2.7 to 2.9 , respectively, in 'Petit Manseng' and 'Vidal blanc' juice.
\end{abstract}

T The proportion of organically produced crops in the United States has been steadily increasing. The 2016 certified organic survey conducted by the U.S. Department of Agriculture's (USDA) National Agricultural Statistics Service (NASS) in conjunction with USDA's Risk Management Agency showed that U.S. farms and ranches produced and sold $\$ 7.6$ billion in certified organic commodities in 2016, up 23\% from 2015. During the same year, the number of

Received for publication 31 Aug. 2020. Accepted for publication 28 Dec. 2020.

Published online 27 January 2021.

${ }^{1}$ Agriculture Research Station, Virginia State University, Petersburg, VA 23806

${ }^{2}$ Virginia Tech Alson H. Smith Jr. Agricultural Research \& Extension Center, 595 Laurel Grove Road, Winchester, VA 22602

We thank the Eppington Foundation for letting us conduct this study on Eppington Plantation Property at 14602 Eppes Falls Road, Chesterfield County, VA.

The project was funded by a U.S. Department of Agriculture-National Institute of Food and Agriculture Block grant no. 2011-540 awarded by the Virginia Department of Agriculture and Consumer Services.

This manuscript (Virginia State University Research Station Article No. 372) was submitted in memory of Michael P. Brandt.

L.K.R. is the corresponding author. E-mail: lrutto@ vsu.edu.

This is an open access article distributed under the CC BY-NC-ND license (https://creativecommons.org/ licenses/by-nc-nd/4.0/).

https://doi.org/10.21273/HORTTECH04726-20 organic farms in the country increased by $11 \%$ to 14,217 and the area increased by $15 \%$ to 5.0 million certified acres. Similarly, organic grape (Vitis sp.) production has increased from 12,575 acres in 2000 to 27,358 acres in 2017 (USDA-NASS, 2017).

Interest in organic or biodynamic viticulture is also high in other wineproducing regions of the world as reported in Willer and Lernoud (2019), and as shown by the volume and diversity of research on the effect of nonconventional management practices on grape quality (e.g., Bunea et al., 2012; NúñezDelicado et al., 2006; Reeve et al., 2005; Vian et al., 2006; Vrček et al., 2011). This interest is driven by increasing awareness of the negative effects that conventional agriculture has on the environment, and a willingness by a section of consumers to pay a premium for food with a smaller environmental footprint (D'Amico et al., 2016; Desta, 2008).

Wine grapes are an important specialty crop in the Commonwealth of Virginia. The Virginia Department of Agriculture and Consumer Services (VDACS) ranked grapes as the 10th most profitable commodity in Virginia with cash receipts of \$19.1 million in 2017 as reported by the USDA (USDANASS, 2019). Virginia wineries and associated vineyards have increased appreciably over the past 10 years to $\approx 291$ wineries (Conway, 2019) and more than 3300 acres of bearing vines (USDANASS, 2019). However, as of 2016, there was only one certified organic winery in the state of Virginia (Quality Certification Service, 2013).

In a 2008 survey conducted by the Virginia Wine Board, industry members identified sustainable production practices $(78.9 \%)$, organic farming systems $(47.7 \%)$, and cultivar and clonal selection and evaluation (71.1\%) as priority areas for state viticulture research (Virginia Vineyards Association, 2008). These research areas are important for Virginia vineyards because of the need to capitalize on growing demand for organic wine and to avoid losing market share to wine regions that have adopted organic production methods. U.S. sales of organic wines reached \$292 million in 2016, representing a $126 \%$ increase over a period of 10 years (Conway, 2018).

In the midwestern and northeastern United States, fungal and other weather-mediated grapevine diseases are typically the most difficult to control organically. Among them, powdery mildew (Uncinula necator), downy mildew (Plasmopara viticola),

\begin{tabular}{llll}
\hline $\begin{array}{l}\text { Units } \\
\text { To convert U.S. to SI, } \\
\text { multiply by }\end{array}$ & U.S. unit & SI unit & $\begin{array}{l}\text { To convert SI to U.S., } \\
\text { multiply by }\end{array}$ \\
\hline 10 & $\%$ & $\mathrm{~g} \cdot \mathrm{L}^{-1}$ & 0.1 \\
0.4047 & $\mathrm{acre}(\mathrm{s})$ & $\mathrm{ha}$ & 2.4711 \\
73.0778 & $\mathrm{fl} \mathrm{oz} / \mathrm{acre}$ & $\mathrm{mL} \cdot \mathrm{ha}^{-1}$ & 0.0137 \\
0.3048 & $\mathrm{ft}$ & $\mathrm{m}$ & 3.2808 \\
3.7854 & $\mathrm{gal}$ & $\mathrm{L}$ & 0.2642 \\
25.4 & inch(es) & $\mathrm{mm}$ & 0.0394 \\
0.4536 & $\mathrm{lb}$ & $\mathrm{kg}$ & 2.2046 \\
1.1209 & $\mathrm{lb} / \mathrm{acre}$ & $\mathrm{kg} \cdot \mathrm{ha}^{-1}$ & 0.8922 \\
70.0532 & $\mathrm{oz} / \mathrm{acre}$ & $\mathrm{g} \cdot \mathrm{ha}^{-1}$ & 0.0143 \\
6.8948 & $\mathrm{psi}$ & $\mathrm{kPa}$ & 0.1450 \\
1.1692 & $\mathrm{pt} / \mathrm{acre}$ & $\mathrm{L} \cdot \mathrm{ha}^{-1}$ & 0.8553 \\
$\left({ }^{\circ} \mathrm{F}-32\right) \div 1.8$ & ${ }^{\circ} \mathrm{F}$ & ${ }^{\circ} \mathrm{C}$ & $\left({ }^{\circ} \mathrm{C} \times 1.8\right)+32$ \\
& & &
\end{tabular}


black rot (Guignardia bidwellii), phomopsis cane and leaf spot (Phomopsis viticola), and botrytis bunch rot (Botrytis cinerea) are some of the biggest challenges in wine grape production (Schilder et al., 2002).

In the current study, disease resistance and potential for organic production of four wine grape cultivars were tested under Virginia conditions. Compared with a majority of competing viticulture regions, Virginia's humid growing season creates an environment conducive to the spread of fungal and other diseases. Black rot, downy mildew, powdery mildew, phomopsis cane and leaf spot, and botrytis bunch rot are common diseases that are especially difficult to control in the humid Virginia environment (Wolf, 2008). Any of these diseases can lead to total crop loss when environmental conditions are conducive, and organic copper, sulfur, and lime sulfur have historically been options for their control. However, these materials are not effective, particularly against black rot, and cannot guarantee vine survival or a healthy crop under typical Virginia conditions (Wolf, 2008).

Two of the cultivars chosen for this study: Arandell and Corot noir, represent new specialty wine grape cultivars developed by the Cornell-Geneva grapevine breeding and genetics program at Cornell University that thus far have limited representation in Virginia. These two red-fruited cultivars have been bred for disease resistance and quality wine characteristics. Trials with these cultivars conducted in New York State by Cornell University with minimal or no agrochemical input produced healthy vines with superior disease resistance and quality wine characteristics (Reisch et al., 2013). The other two cultivars, Petit Manseng and Vidal blanc, both white, were chosen based on their superior resistance against black rot compared with other traditional wine grapes. These cultivars are also known for high-quality wine and are already represented in Virginia viticulture.

\section{Materials and methods}

Site AND CUlTivar SEleCtion. The study was conducted at a vineyard established in 2012 at the Eppington Plantation (lat. $37^{\circ} 17^{\prime} \mathrm{N}$, long. $77^{\circ} 43^{\prime} \mathrm{W}$ ) in Chesterfield County, VA, using the grape cultivars Arandell, Corot noir, Petit Manseng, and Vidal blanc. Certified stock for 'Petit Manseng' was purchased from Novavine (Santa Rosa, $\mathrm{CA}$ ), and that for 'Arandell', 'Corot noir', and 'Vidal blanc' was supplied by Double A Vineyards Inc. (Fredonia, NY). Cultivar selection was based on fungal disease resistance and potential wine quality.

SPRAY PROGRAMS. Two organic spray programs (organic $A$ and $B$ ) using pesticides certified by the Organic Materials Review Institute (OMRI), and a conventional program (Table l) were designed to assess the disease management of downy mildew, powdery mildew, black rot, and phomopsis cane and leaf spot. Both organic spray programs were formulated using a foundation of fixed copper [copper hydroxide (Nucop HB; Albaugh, Ankey, IA)], hydrated lime [calcium hydroxide (APG Lime Corp., Kimballton, VA)], and sulfur (Kumulus DF; BASF, Florham Park, NJ), with the addition of Bacills subtilis (Serenade ASO; BASF, Florham Park, NJ) in one program (organic B). Bacillus subtilis is not labeled for downy mildew, black rot, and phomopsis cane and leaf spot but has been shown to improve the management of these diseases in other climates (Ellis and Nita, 2004; Schilder, 2008). The sprays were conducted on a weekly basis beginning two weeks post budbreak on 6 May 2013 and 3 May 2014. A 15-L backpack sprayer (425; Solo, Newport News, VA) equipped with a piston pump and an adjustable brass nozzle was used to deliver the mixtures at a pressure of 60 psi. During the 2014 growing season an organic adjuvant (Nu Film P; Miller Chemical and Fertilizer Co., Hanover, PA) was included in both organic spray programs.

Experimental layout. The three spray programs: organic A (12.3 oz) acre copper $+1.8 \mathrm{lb} /$ acre hydrated lime $+1.9 \mathrm{lb} /$ acre sulfur); organic B (12.3 oz/acre copper $+1.8 \mathrm{lb} /$ acre hydrated lime $+1.9 \mathrm{lb} /$ acre sulfur +

Table 1. Products applied in 2013 and 2014 in a study to evaluate cultivars and spray programs for organic wine grape production in Virginia.

\begin{tabular}{|c|c|c|c|c|c|}
\hline $\begin{array}{l}\text { Spray } \\
\text { program }^{z}\end{array}$ & Product & Active ingredient & $\begin{array}{c}\text { Active } \\
\text { ingredient } \\
\text { by wt (\%) }\end{array}$ & $\begin{array}{l}\text { Rate/acre } \\
(\text { a.i. })^{y}\end{array}$ & Spray timing \\
\hline & Hydrated lime & Calcium hydroxide & $90-100$ & $1.8 \mathrm{lb}$ & Weekly interval \\
\hline & Sulfur & Sulfur & 80 & $1.9 \mathrm{lb}$ & Weekly interval \\
\hline \multirow[t]{2}{*}{ Organic B } & Copper & Copper hydroxide & 77 & $12.3 \mathrm{oz}$ & Weekly interval \\
\hline & $\begin{array}{l}\text { Bacillus subtilis QST } \\
\quad 713\end{array}$ & B. subtilis & 1.34 & $1.0 \mathrm{fl} \mathrm{oz}$ & Weekly interval \\
\hline \multirow[t]{2}{*}{ Conventional } & Mancozeb & $\begin{array}{l}\text { Zinc ion and manganese } \\
\text { ethylene-bis- } \\
\text { dithiocarbamate ion }\end{array}$ & 75 & $2.3 \mathrm{lb}$ & $\begin{array}{c}\text { Weekly interval (removed } 66 \mathrm{~d} \\
\text { before typical harvest date) }\end{array}$ \\
\hline & Phosphorous acid & Potassium phosphite & 54.5 & $1.1 \mathrm{pt}$ & $\begin{array}{l}\text { Weekly interval (replaced } \\
\text { mancozeb for the } 66 \mathrm{~d} \text { before } \\
\text { typical harvest date interval) }\end{array}$ \\
\hline
\end{tabular}

${ }^{\mathrm{z}}$ An organic surfactant (Nu Film P; Miller Chemical and Fertilizer Co., Hanover, PA) was added to both organic spray programs during the 2014 growing season.

${ }^{\mathrm{y}} \mathrm{l} \mathrm{oz} /$ acre $=70.0532 \mathrm{~g} \cdot \mathrm{ha}^{-1}, \mathrm{l} \mathrm{lb} /$ acre $=1.1209 \mathrm{~kg} \cdot \mathrm{ha}^{-1}, \mathrm{l} \mathrm{fl} \mathrm{oz} /$ acre $=73.0778 \mathrm{~mL} \cdot \mathrm{ha}^{-1}, 1 \mathrm{pt} / \mathrm{acre}=1.1692 \mathrm{~L} \cdot \mathrm{ha}^{-1}$. 
$1.0 \mathrm{oz} /$ acre B. subtilis); conventional [2.3 $\mathrm{lb} /$ acre mancozeb (Manzate Prostick; United Phosphorus, King of Prussia, PA) + $1.1 \mathrm{lb} /$ acre phosphorus acid (prophyt; Helena Chemical Company, Collierville, TN) + 1.9 $\mathrm{lb} /$ acre sulfur] were assigned to plots planted with four-vine panels of the four wine grape cultivars. Spacing at planting was $4 \mathrm{ft}$ between vines and 7 ft between rows. A split plot design was used whereby treatments were blocked by row (north-south orientation) with spray treatments (plots) randomly distributed within the block and cultivars within the plot. There were four replicates per treatment with a 10 -ft buffer between plots, and the conventional block was separated from organic A and B blocks by a $100-\mathrm{ft}$ buffer. At training, cane pruned, vertical shoot positioning (VSP) system was adopted with two cordons trained along the lowest of three support wires and upright shoots sandwiched between the higher two sets of wires.

Disease assessment. To minimize the potential effects of disease spread from neighboring panels, the middle two vines of a four-vine panel were selected for disease assessment. Disease scoring was done during the growing season on each vine by randomly selecting three shoots per vine and five leaves per shoot (120 leaves per cultivar) for visual assessment of disease incidence (number of diseased leaves or clusters per total number sampled) and severity (percentage of leaf/cluster area affected). In total, four leaf assessments were conducted in 2013 (22 July, 6 Aug., 20 Aug., and 3 Sept.), and four leaf and fruit cluster assessments were conducted in 2014 (18 June, 2 July, 16 July, and 28 July).

FRUIT HARVESTING AND PROCESSING. The 2014 crop was harvested starting 10 Aug. ( $12 \mathrm{~d}$ after the last spray). Data on yield per vine was recorded and berries were sampled and prepared for analysis of total soluble solids, $\mathrm{pH}$, and titratable acidity following methods described by Esteban et al. (1999). Total soluble solids content was measured using a portable handheld refractometer (MASTER53T; Atago USA, Bellevue, WA) with automatic temperature compensation. A benchtop pH meter $(\mathrm{S} 220 \mathrm{pH} /$ ion meter; Mettler Toledo, Columbus, $\mathrm{OH}$ ) was used to measure juice $\mathrm{pH}$, and titratable acidity was determined by titration to an endpoint of $\mathrm{pH} 8.2$ $\left(20{ }^{\circ} \mathrm{C}\right)$ with results expressed as grams per liter of tartaric acid.

Statistical analysis. The performance of cultivars and spray programs and their interaction were compared by analysis of variance using a linear mixed model (SAS/STAT version 9.4; SAS Institute, Cary, NC) with cultivar and spray program considered as fixed effects and block as a random effect. Where significant, treatment means were separated by Duncan's multiple range test $(P \leq$ $0.05)$.

\section{Results}

Climatic data. Total precipitation for the 2013 growing season was higher than in 2014 and exceeded the 30-year (1970-2000) mean for the region (Table 2 ). Total precipitation for the 2014 growing season was typical for the study site, and mean minimum and maximum temperatures in 2013 and 2014 deviated only slightly from historical means (Table 2).

SPray performance. Comparisons of disease incidence and severity within cultivar and treatment in 2013 show that Arandell was most resistant to observed fungal diseases as compared with the other cultivars. Both disease incidence and severity were significantly higher in 'Vidal blanc', and intermediate in 'Corot noir' and 'Petit Manseng', with no significant differences observed between the two cultivars for both disease indices $(\mathrm{Ta}-$ ble 3 ). In 2014, similar trends were observed, but percent incidence and severity were much lower than in 2013. Similar to 2013, 'Arandell' showed significantly higher resistance with very low incidences of black rot and phomopsis cane and leaf spot, and no downy mildew infection (Table 4).

Across cultivars, the conventional spray program proved to be more effective than both organic spray programs, except in Arandell where there were no significant differences between treatments in 2013 . The organic A treatment was found to be least effective among treatments with the worst performance observed in the cultivar Vidal blanc (Table 5). Both disease incidence and severity were found to be much lower in 2014 (Table 6). During both years, cultivar and spray program, and their interactions were found to be highly significant (Tables 3-6), except in the case of black rot incidence and phomopsis severity in 2014 (Table 4).

BERRY YIELD AND QUALITY. Black rot was the only disease detected on fruit clusters in 2014. The organic treatments had significantly less black rot than the conventional treatment, while among cultivars, Arandell recorded significantly less black rot relative to Petit Manseng and Vidal blanc. Similar to disease expression on foliage, cultivar and spray program, and their interaction were found to be highly significant with respect to black rot in fruit clusters (Table 7). Due to bird predation, 'Arandell' was harvested early (22 Aug.) to avoid losing the entire crop. The other cultivars were covered with bird netting on 26 Aug., but significant berry loss still occurred and the average weights

Table 2. Rainfall and temperature data for Petersburg, VA [lat. $37^{\circ} 24^{\prime} \mathrm{N}$, long. $77^{\circ} 39^{\prime} \mathrm{W}$ elevation $134 \mathrm{ft}(40.8 \mathrm{~m})$ ] during the 2013 and 2014 growing seasons when a study was conducted to evaluate cultivars and spray programs for organic wine grape production in Virginia. Historical (1970-2000) data are for

Richmond International Airport, Richmond, VA [lat. $37^{\circ} 30^{\prime} \mathrm{N}$, long. $77^{\circ} 19^{\prime} \mathrm{W}$ elevation $150 \mathrm{ft}(45.7 \mathrm{~m})]$.

\begin{tabular}{|c|c|c|c|c|c|c|}
\hline \multirow[b]{2}{*}{ Month } & \multicolumn{3}{|c|}{${\text { Precipitation (inches) }{ }^{\mathrm{z}}}$} & \multicolumn{3}{|c|}{ Mean temp range $\left({ }^{\circ} F\right)^{\mathrm{z}}$} \\
\hline & Historical $^{\mathrm{y}}$ & 2013 & 2014 & Historical $^{\mathbf{x}}$ & 2013 & 2014 \\
\hline Mar & 4.08 & 2.65 & 2.34 & $36.9-59.6$ & $30.6-50.4$ & $30.4-53.2$ \\
\hline April & 3.17 & 4.09 & 3.42 & $45.3-70.2$ & $46.8-71.4$ & $44.4-70.7$ \\
\hline May & 3.89 & 3.48 & 0.71 & $54.7-77.7$ & $53.8-75.4$ & $56.1-79.9$ \\
\hline June & 3.47 & 9.32 & 3.79 & $63.3-85.2$ & $65.2-84.6$ & $64.0-86.2$ \\
\hline July & 4.67 & 4.60 & 4.72 & $68.3-89.0$ & $70.5-86.7$ & $67.1-87.1$ \\
\hline Augus & 4.10 & 6.12 & 5.89 & $66.8-87.2$ & $64.9-82.8$ & $65.5-83.8$ \\
\hline September & 3.89 & 3.56 & 2.48 & $60.0-81.1$ & $58.1-81.0$ & $63.1-80.1$ \\
\hline October & 3.54 & 5.23 & 2.17 & $47.4-70.6$ & $51.3-70.5$ & $48.6-71.4$ \\
\hline
\end{tabular}

${ }^{\mathrm{z}} \mathrm{l}$ inch $=25.4 \mathrm{~mm},\left({ }^{\circ} \mathrm{F}-32\right) \div 1.8={ }^{\circ} \mathrm{C}$.

${ }^{\mathrm{y}}$ National Centers for Environmental Information (2020). 
Table 3. Mean disease incidence (percentage of leaves exhibiting symptoms) and severity (percentage of leaf coverage) during the $\mathbf{2 0 1 3}$ growing season in a study to evaluate cultivars and spray programs for organic wine grape production in Virginia.

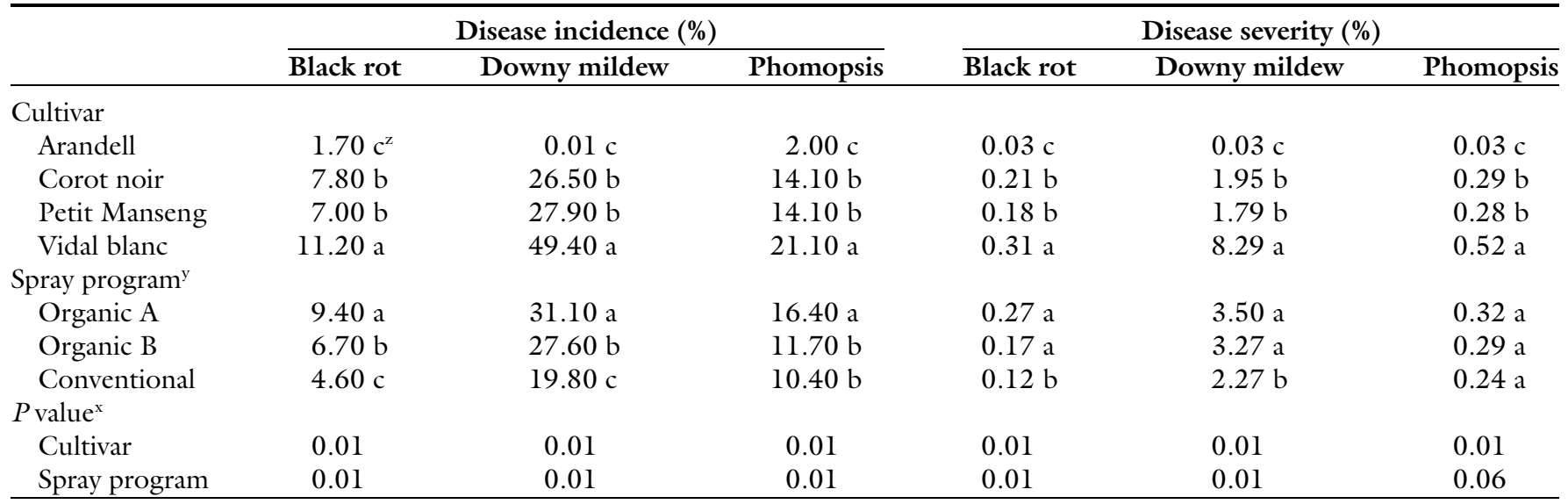

${ }^{\mathrm{z}}$ Column means followed by different letters within cultivar and spray program are significantly different (Duncan's multiple range test at $P \leq 0.05$ ).

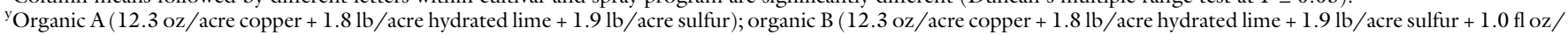

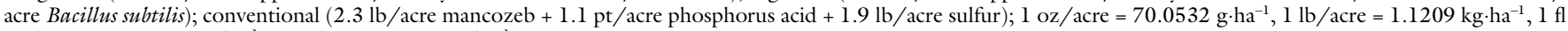
$\mathrm{oz} /$ acre $=73.0778 \mathrm{~mL} \cdot \mathrm{ha}^{-1}, \mathrm{l} \mathrm{pt} /$ acre $=1.1692 \mathrm{~L} \cdot \mathrm{ha}^{-1}$.

${ }^{\mathrm{x}}$ Probability values significant at $\alpha \leq 0.05$.

Table 4. Mean disease incidence (percentage of leaves exhibiting symptoms) and severity (percentage of leaf coverage) during the $\mathbf{2 0 1 4}$ growing season in a study to evaluate cultivars and spray programs for organic wine grape production in Virginia.

\begin{tabular}{|c|c|c|c|c|c|c|}
\hline & \multicolumn{3}{|c|}{ Disease incidence (\%) } & \multicolumn{3}{|c|}{ Disease severity (\%) } \\
\hline & Black rot & Downy mildew & Phomopsis & Black rot & Downy mildew & Phomopsis \\
\hline \multicolumn{7}{|l|}{ Cultivar } \\
\hline Corot noir & $0.03 \mathrm{~b}$ & $0.004 \mathrm{ab}$ & $0.057 \mathrm{~b}$ & $0.05 \mathrm{~b}$ & $0.009 \mathrm{ab}$ & $0.080 \mathrm{~b}$ \\
\hline Petit Manseng & $0.03 \mathrm{~b}$ & $0.006 \mathrm{a}$ & $0.042 \mathrm{~b}$ & $0.07 \mathrm{~b}$ & $0.012 \mathrm{a}$ & $0.050 \mathrm{c}$ \\
\hline Vidal blanc & $0.06 \mathrm{a}$ & $0.006 \mathrm{a}$ & $0.092 \mathrm{a}$ & $0.14 \mathrm{a}$ & $0.012 \mathrm{a}$ & $0.130 \mathrm{a}$ \\
\hline Organic B & $0.03 \mathrm{a}$ & $0.005 \mathrm{ab}$ & $0.058 \mathrm{a}$ & $0.05 \mathrm{~b}$ & $0.009 \mathrm{ab}$ & $0.08 \mathrm{a}$ \\
\hline Conventional & $0.04 \mathrm{a}$ & $0.006 \mathrm{a}$ & $0.036 \mathrm{~b}$ & $0.10 \mathrm{a}$ & $0.014 \mathrm{a}$ & $0.04 \mathrm{a}$ \\
\hline \multicolumn{7}{|l|}{$P$ value ${ }^{\mathrm{x}}$} \\
\hline Cultivar & 0.01 & 0.001 & 0.001 & 0.01 & 0.001 & 0.01 \\
\hline Spray program & 0.10 & 0.001 & 0.01 & 0.01 & 0.001 & 0.14 \\
\hline
\end{tabular}

${ }^{\mathrm{z}}$ Column means followed by different letters within cultivar and spray program are significantly different (Duncan's multiple range test at $P \leq 0.05$ ).

${ }^{\mathrm{y}}$ Organic A $(12.3 \mathrm{oz} / \mathrm{acre}$ copper $+1.8 \mathrm{lb} / \mathrm{acre}$ hydrated lime $+1.9 \mathrm{lb} / \mathrm{acre}$ sulfur $)$; organic B $(12.3 \mathrm{oz} / \mathrm{acre}$ copper $+1.8 \mathrm{lb} / \mathrm{acre}$ hydrated lime $+1.9 \mathrm{lb} / \mathrm{acre}$ sulfur $+1.0 \mathrm{fl} \mathrm{oz} /$

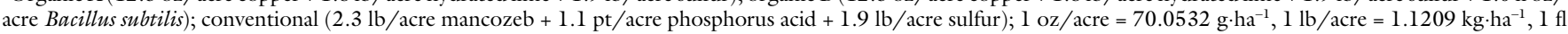
$\mathrm{oz} /$ acre $=73.0778 \mathrm{~mL} \cdot \mathrm{ha}^{-1}, \mathrm{l} \mathrm{pt} /$ acre $=1.1692 \mathrm{~L} \cdot \mathrm{ha}^{-1}$.

${ }^{\mathrm{x}}$ Probability values significant at $\alpha \leq 0.05$.

reported per vine are not representative (Table 8). Analysis of the 2014 crop showed that in all cultivars, soluble solids concentration, $\mathrm{pH}$, and titratable acidity were within acceptable ranges for use in wine making. As expected, cultivar was a significant factor, while spray program did not influence fruit quality. No significant interaction was observed between the two factors (Table 8 ).

\section{Discussion}

Total precipitation for the 2013 growing season was higher than in 2014 and exceeded the 30-year mean for central Virginia where the vineyard is located (Table 2). A review of historical (1970-2000) climate data for the region (National Centers for Environmental Information, 2020) shows that the rainfall total in June 2013 was higher than the historical mean by 5.85 inches, potentially promoting higher-than-normal disease inoculum production and incidence for the rest of the season. Due to the increased moisture in 2013 and buildup of inoculum from the 2012 growing season, the incidence and severity of phomopsis cane and leaf spot, black rot, and downy mildew were considerable. Total precipitation for the 2014 growing season was typical for the experimental site ( $\mathrm{Ta}$ ble 2). However, higher than normal precipitation is becoming more frequent suggesting a climatic trend that may complicate wine grape production in Virginia and the northeastern United States.

An analysis of the effectiveness of the three spray programs in inhibiting downy mildew, black rot, and phomopsis cane and leaf spot showed statistically significant differences $(P \leq 0.05)$. Powdery mildew was not detected in any disease assessment in this study. Comparisons of disease incidence and severity within cultivar and treatment in 2013 show that Arandell was most resistant to observed fungal diseases as compared with the other cultivars. Both measures were significantly higher in 'Vidal blanc', and intermediate in 'Corot noir' and 
Table 5. Mean disease incidence (percentage of leaves exhibiting symptoms) and severity (percentage of leaf coverage) across cultivars during the $\mathbf{2 0 1 3}$ growing season in a study to evaluate cultivars and spray programs for organic wine grape production in Virginia.

\begin{tabular}{|c|c|c|c|c|c|c|c|}
\hline & \multirow[b]{2}{*}{ Spray program ${ }^{z}$} & \multicolumn{3}{|c|}{ Disease incidence (\%) } & \multicolumn{3}{|c|}{ Disease severity (\%) } \\
\hline & & Black rot & Downy mildew & Phomopsis & Black rot & Downy mildew & Phomopsis \\
\hline \multicolumn{8}{|l|}{ Cultivar } \\
\hline \multirow{2}{*}{ Arandell } & Organic B & $1.25 \mathrm{~d}$ & $0.21 \mathrm{~h}$ & $1.25 \mathrm{f}$ & $0.02 \mathrm{~d}$ & $0.01 \mathrm{~d}$ & $0.02 \mathrm{~d}$ \\
\hline & Conventional & $1.46 \mathrm{~d}$ & $0.21 \mathrm{~h}$ & $1.00 \mathrm{f}$ & $0.04 \mathrm{~d}$ & $0.01 \mathrm{~d}$ & $0.01 \mathrm{~d}$ \\
\hline Corot noir & Organic A & $11.46 \mathrm{ab}$ & $32.50 \mathrm{de}$ & $18.00 \mathrm{bc}$ & $0.33 \mathrm{ab}$ & $1.97 \mathrm{c}$ & $0.34 \mathrm{~b}$ \\
\hline \multirow[t]{3}{*}{ Petit Manseng } & Organic A & $9.58 \mathrm{abc}$ & $38.96 \mathrm{~cd}$ & $17.29 \mathrm{bc}$ & $0.26 \mathrm{bc}$ & $2.34 \mathrm{c}$ & $0.28 \mathrm{bc}$ \\
\hline & Organic B & $6.25 \mathrm{bcd}$ & $29.17 \mathrm{e}$ & $14.79 \mathrm{bcd}$ & $0.14 \mathrm{~cd}$ & $2.30 \mathrm{c}$ & $0.30 \mathrm{~b}$ \\
\hline & Conventional & $5.21 \mathrm{~cd}$ & $15.63 \mathrm{~g}$ & $10.21 \mathrm{de}$ & $0.13 \mathrm{~cd}$ & $0.72 \mathrm{~cd}$ & $0.26 \mathrm{bc}$ \\
\hline \multirow[t]{2}{*}{ Vidal blanc } & Organic A & $14.38 \mathrm{a}$ & $50.63 \mathrm{ab}$ & $26.04 \mathrm{a}$ & $0.43 \mathrm{a}$ & $9.64 \mathrm{a}$ & $0.59 \mathrm{a}$ \\
\hline & Organic B & $9.58 \mathrm{abc}$ & $54.38 \mathrm{a}$ & $18.96 \mathrm{~b}$ & $0.26 \mathrm{bc}$ & $8.58 \mathrm{a}$ & $0.57 \mathrm{a}$ \\
\hline \multicolumn{2}{|c|}{ Cultivar $\times$ spray program } & 0.01 & 0.01 & 0.01 & 0.01 & 0.01 & 0.01 \\
\hline
\end{tabular}

${ }^{\mathrm{z}}$ Organic A ( $12.3 \mathrm{oz} /$ acre copper $+1.8 \mathrm{lb} /$ acre hydrated lime $+1.9 \mathrm{lb} /$ acre sulfur $) ;$ organic B $(12.3 \mathrm{oz} / \mathrm{acre}$ copper $+1.8 \mathrm{lb} / \mathrm{acre} \mathrm{hydrated} \mathrm{lime}+1.9 \mathrm{lb} / \mathrm{acre}$ sulfur $+1.0 \mathrm{fl}$ oz $/$ acre Bacillus subtilis $)$; conventional $(2.3 \mathrm{lb} /$ acre mancozeb $+1.1 \mathrm{pt} /$ acre phosphorus acid $+1.9 \mathrm{lb} / \mathrm{acre}$ sulfur $) ; 1 \mathrm{oz} / \mathrm{acre}=70.0532 \mathrm{~g} \cdot \mathrm{ha}{ }^{-1}, 1 \mathrm{lb} / \mathrm{acre}=1.1209 \mathrm{~kg} \cdot \mathrm{ha}{ }^{-1}, 1 \mathrm{fl}$ $\mathrm{oz} /$ acre $=73.0778 \mathrm{~mL} \cdot \mathrm{ha}^{-1}, \mathrm{l} \mathrm{pt} / \mathrm{acre}=1.1692 \mathrm{~L} \cdot \mathrm{ha}^{-1}$.

${ }^{y}$ Means within columns followed by different letters are significantly different (Duncan's multiple range test at $P \leq 0.05$ ).

${ }^{\mathrm{x}}$ Probability values significant at $\alpha \leq 0.05$.

Table 6. Mean disease incidence (percentage of leaves exhibiting symptoms) and severity (percentage of leaf coverage) across cultivars during the $\mathbf{2 0 1 4}$ growing season in a study to evaluate cultivars and spray programs for organic wine grape production in Virginia.

\begin{tabular}{|c|c|c|c|c|c|c|c|}
\hline & \multirow[b]{2}{*}{ Spray program $^{z}$} & \multicolumn{3}{|c|}{ Disease incidence (\%) } & \multicolumn{3}{|c|}{ Disease severity (\%) } \\
\hline & & Black rot & Downy mildew & Phomopsis & Black rot & Downy mildew & Phomopsis \\
\hline \multicolumn{8}{|l|}{ Cultivar } \\
\hline & Organic B & $0.004 \mathrm{~d}$ & $0.000 \mathrm{~b}$ & $0.002 \mathrm{f}$ & $0.016 \mathrm{e}$ & $0.000 \mathrm{a}$ & $0.002 \mathrm{f}$ \\
\hline & Conventional & $0.016 \mathrm{~cd}$ & $0.000 \mathrm{~b}$ & $0.008 \mathrm{f}$ & $0.020 \mathrm{e}$ & $0.000 \mathrm{a}$ & $0.008 \mathrm{ef}$ \\
\hline Corot noir & Organic A & $0.022 \mathrm{~cd}$ & $0.000 \mathrm{~b}$ & $0.071 \mathrm{bc}$ & $0.039 \mathrm{de}$ & $0.000 \mathrm{a}$ & $0.102 \mathrm{bc}$ \\
\hline \multirow[t]{3}{*}{ Petit Manseng } & Organic A & $0.037 \mathrm{bc}$ & $0.004 \mathrm{ab}$ & $0.045 \mathrm{~cd}$ & $0.072 \mathrm{cde}$ & $0.004 \mathrm{a}$ & $0.052 \mathrm{de}$ \\
\hline & Organic B & $0.014 \mathrm{~cd}$ & $0.006 \mathrm{ab}$ & $0.037 \mathrm{de}$ & $0.033 \mathrm{de}$ & $0.010 \mathrm{a}$ & $0.039 \mathrm{def}$ \\
\hline & Conventional & $0.037 \mathrm{bc}$ & $0.006 \mathrm{ab}$ & $0.043 \mathrm{~cd}$ & $0.093 \mathrm{bcd}$ & $0.020 \mathrm{a}$ & $0.052 \mathrm{de}$ \\
\hline \multirow[t]{2}{*}{ Vidal blanc } & Organic A & $0.052 \mathrm{ab}$ & $0.000 \mathrm{~b}$ & $0.093 \mathrm{~b}$ & $0.093 \mathrm{bcd}$ & $0.000 \mathrm{a}$ & $0.137 \mathrm{~b}$ \\
\hline & Organic B & $0.070 \mathrm{a}$ & $0.010 \mathrm{a}$ & $0.131 \mathrm{a}$ & $0.143 \mathrm{ab}$ & $0.020 \mathrm{a}$ & $0.206 \mathrm{a}$ \\
\hline \multicolumn{2}{|c|}{ Cultivar $\times$ spray program } & 0.001 & 0.001 & 0.001 & 0.001 & 0.001 & 0.001 \\
\hline
\end{tabular}

${ }^{\mathrm{z}}$ Organic A ( $12.3 \mathrm{oz} /$ acre copper $+1.8 \mathrm{lb} /$ acre hydrated lime $+1.9 \mathrm{lb} /$ acre sulfur $)$; organic $\mathrm{B}(12.3 \mathrm{oz} / \mathrm{acre}$ copper $+1.8 \mathrm{lb} / \mathrm{acre}$ hydrated lime $+1.9 \mathrm{lb} / \mathrm{acre}$ sulfur $+1.0 \mathrm{fl} \mathrm{oz} /$ acre Bacillus subtilis); conventional $(2.3 \mathrm{lb} / \mathrm{acre}$ mancozeb $+1.1 \mathrm{pt} / \mathrm{acre}$ phosphorus acid $+1.9 \mathrm{lb} / \mathrm{acre}$ sulfur $) ; 1 \mathrm{oz} / \mathrm{acre}=70.0532 \mathrm{~g} \cdot \mathrm{ha}^{-1}, 1 \mathrm{lb} / \mathrm{acre}=1.1209 \mathrm{~kg} \cdot \mathrm{ha}{ }^{-1}, 1 \mathrm{fl}$ $\mathrm{oz} /$ acre $=73.0778 \mathrm{~mL} \cdot \mathrm{ha}^{-1}, \mathrm{l} \mathrm{pt} /$ acre $=1.1692 \mathrm{~L} \cdot \mathrm{ha}^{-1}$.

${ }^{\mathrm{y}}$ Means within columns followed by different letters are significantly different (Duncan's multiple range test at $P \leq 0.05$ ).

Probability values significant at $\alpha \leq 0.05$.

'Petit Manseng' with no significant differences observed between the two intermediate cultivars. In 2014, similar trends were observed, but percent incidence and severity were much lower than in 2013. Similar to
2013, 'Arandell' showed significantly higher resistance with very low incidences of black rot and phomopsis cane and leaf spot, and no symptoms of downy mildew. As observed by Schilder et al. (2002), the timing of application for organic products used to manage plant disease is critical because most of them play a protective rather than curative role. In the current study, treatments were applied at a weekly interval, but it is possible that 
lower frequencies could be adopted if information from disease forecasting and early warning systems were taken into consideration. Nita et al. (2006a) have already reported improved protective capacity of conventional fungicides applied in response to infection periods predicted for phomopsis cane and leaf spot by an early warning system. The effectiveness of disease forecasting models in predicting disease incidence and severity (Erincik et al., 2003), and for reducing the frequency of fungicide sprays to control downy mildew (Madden et al., 2000) and phomopsis cane and leaf spot (Nita et al., 2006a) suggest they could be applied directly to disease management programs employing organic products.

Among treatments, the lowest overall measure of disease incidence and severity was observed in the

Table 7. Mean incidence (percentage of clusters exhibiting symptoms) of black rot in fruit harvested in $\mathbf{2 0 1 4}$ from a study to evaluate cultivars and spray programs for organic wine grape production in Virginia.

Disease incidence (\%)

\begin{tabular}{lc} 
Cultivar & \\
Arandell & $0.00 \mathrm{~b}^{\mathrm{z}}$ \\
Corot noir & $0.02 \mathrm{ab}$ \\
Petit Manseng & $0.03 \mathrm{a}$ \\
Vidal blanc & $0.03 \mathrm{a}$ \\
Spray program & \\
Organic A & \\
Organic B & $0.01 \mathrm{~b}$ \\
Conventional & $0.01 \mathrm{~b}$ \\
Pvalue & $0.06 \mathrm{a}$ \\
Cultivar & \\
Spray program & 0.01 \\
Cultivar $\times$ spray program & 0.01 \\
\hline
\end{tabular}

$\overline{{ }^{z} \text { Column means within cultivar and spray program followed by different letters are significantly different (Duncan's }}$ multiple range test at $P \leq 0.05$ ).

${ }^{\mathrm{y}}$ Organic A (12.3 oz/acre copper $+1.8 \mathrm{lb} /$ acre hydrated lime $+1.9 \mathrm{lb} /$ acre sulfur $)$; organic B $(12.3 \mathrm{oz} / \mathrm{acre}$ copper $+1.8 \mathrm{lb} /$ acre hydrated lime $+1.9 \mathrm{lb} /$ acre sulfur $+1.0 \mathrm{fl} \mathrm{oz} /$ acre Bacillus subtilis); conventional $(2.3 \mathrm{lb} / \mathrm{acre}$ mancozeb $+1.1 \mathrm{pt} /$ acre phosphorus acid $+1.9 \mathrm{lb} /$ acre sulfur $) ; \mathrm{l} \mathrm{oz} /$ acre $=70.0532 \mathrm{~g} \cdot \mathrm{ha}^{-1}, \mathrm{l} \mathrm{lb} / \mathrm{acre}=1.1209$ $\mathrm{kg} \cdot \mathrm{ha}^{-1}, \mathrm{l} \mathrm{fl} \mathrm{oz} / \mathrm{acre}=73.0778 \mathrm{~mL} \cdot \mathrm{ha}^{-1}, \mathrm{l} \mathrm{pt} / \mathrm{acre}=1.1692 \mathrm{~L} \cdot \mathrm{ha}^{-1}$

xProbability values significant at $\alpha \leq 0.05$. conventional spray program in 2013 . With the exception of phomopsis cane and leaf spot incidence where both the conventional and organic B spray programs were found to be equally effective, disease incidence and severity were significantly lower in the conventional spray program, whereas the inclusion of B. subtilis in the organic B spray program significantly reduced the incidence of black rot and downy mildew as compared with the organic A program. There were no significant differences in phomopsis severity between treatments. Treatment data for 2014 was mixed. Both organic spray treatments were significantly more effective than the conventional treatment in the control of black rot while the conventional treatment significantly reduced the incidence but not the severity of phomopsis cane and leaf spot. On average, the organic A treatment was more effective than the conventional treatment in 2014 with the organic B program being intermediate.

One of the challenges of adopting organic products for plant disease management is the everchanging suite of products listed by OMRI (2020) owing to a relatively shorter process for registration of organic products. Some products also get deregistered calling for constant vigilance by organic

Table 8. Fruit chemistry and yield data for the 2014 growing season in a study to evaluate cultivars and spray programs for organic wine grape production in Virginia.

\begin{tabular}{|c|c|c|c|c|c|}
\hline & Spray program ${ }^{z}$ & Soluble solids (\%) & $\mathrm{pH}$ & Titratable acidity $\left(\mathrm{g} \cdot \mathrm{L}^{-1}\right)^{\mathrm{y}}$ & $\operatorname{Avg~wt}(\mathrm{lb} / \text { vine })^{\mathrm{x}}$ \\
\hline \multicolumn{6}{|l|}{ Cultivar } \\
\hline \multirow{3}{*}{ Arandell } & Organic A & 18.7 & 3.3 & 8.0 & 2.7 \\
\hline & Organic B & 20.1 & 3.3 & 8 & 2.2 \\
\hline & Conventional & 18.8 & 3.3 & 8.0 & 2.3 \\
\hline \multirow[t]{2}{*}{ Corot noir } & Organic A & 20.0 & 3.4 & 7.8 & 2.6 \\
\hline & Organic B & 20.2 & 3.4 & 7.6 & 3.3 \\
\hline \multirow{2}{*}{ Petit Manseng } & Organic B & 23.9 & 2.7 & 9.6 & 1.4 \\
\hline & Conventional & 24.4 & 2.8 & 9.4 & 1.3 \\
\hline \multirow[t]{3}{*}{ Vidal blanc } & Organic A & 21.7 & 2.8 & 7.8 & 4.9 \\
\hline & Organic B & 21.0 & 2.9 & 7.9 & 4.9 \\
\hline & Conventional & 21.5 & 2.9 & 8.0 & 4.9 \\
\hline \multicolumn{6}{|l|}{$P$ valuesw } \\
\hline
\end{tabular}


farmers. For example, by 2014 the adjuvant (Nu Film 17, Miller Chemical and Fertilizer Co.) selected for use in the study because of its capacity to improve the biological efficacy of $B$. subtilis (Schilder, 2008) had lost its organic registration and had to be replaced by a next generation product (Nu Film P).

Comparisons across cultivars show that the conventional program was relatively more effective than organic sprays except in Arandell where no significant differences were observed between treatments in 2013 . Overall, the organic A treatment was least effective with the worst performance observed in 'Vidal blanc'. The results show that the organically registered fungicide $B$. subtilis is effective in reducing the severity and incidence of black rot and phomopsis cane and leaf spot as previously reported (Schilder et al., 2002). The significant differences observed between organic spray $A$ and $B$ in the incidence of phomopsis cane and leaf spot on 'Corot noir', 'Petit Manseng', and 'Vidal blanc' suggest that B. subtilis can improve the efficacy of organic fungicides used in this study. Disease incidence and severity were much lower in 2014. However, similar to 2013 'Vidal blanc' recorded the highest, and 'Arandell' the lowest infection irrespective of treatment. Downy mildew was not observed in Arandell, and no significant differences in severity were found within treatment and across cultivars. Data from 2014 show that the organic spray programs tested can perform as well or better than conventional sprays in a typical Virginia year. The trial outlined significant disease resistance in 'Arandell' and its potential for organic production in Virginia. Disease incidence and severity of phomopsis cane and leaf spot, black rot, and downy mildew detected on Arandell were consistently and significantly lower than in the other three cultivars, and even during the wetter than normal 2013 growing season, symptoms of these diseases were almost undetectable. This observation suggests that in the long run, new disease-resistant cultivars coupled with improved organic products may make organic viticulture economically feasible in Virginia and the eastern United States.

During the 2014 growing season, the first harvest was conducted. Black rot was the only disease detected on fruit clusters in 2014 with the organic treatments recording significantly less black rot incidence than the conventional treatment as did 'Arandell' compared with 'Petit Manseng' and 'Vidal blanc'. Extensive bird predation was observed during the season, and 'Arandell' was harvested early (22 Aug.) to save some of the crop. On 26 Aug., the remaining cultivars were covered with bird netting, but substantial berry loss still occurred and the average weights reported per vine and cultivar are not truly representative for the season. However, chemical analysis of berries harvested in 2014 showed soluble solids content, $\mathrm{pH}$, and titratable acidity within acceptable range for good vintage in both white and red cultivars (Ough and Singleton, 1968).

CONCLUSION AND MANAGEMENT IMPLICATIONS. Recent rainfall patterns suggest that there may be seasons in Virginia and the greater eastern United States when both conventional and organic programs may not be fully effective in controlling common grapevine diseases. However, our results show that in most years, judicious selection of products, strict field scouting, reliance on the most advanced disease prediction models, and application of new or improved organic products may enable organic grape production in Virginia. The strong performance by 'Arandell' suggests it can be a candidate for organic production under favorable conditions. Our findings highlight the importance of breeding for disease resistance and confirm that cultivar selection may be one of the most important factors in organic viticulture.

Opportunities exist for further research to support organic wine grape production including development of disease prediction and early-warning models aligned with organic systems and products. Cross-cutting studies like those already conducted under conventional production [e.g., agronomic systems (Pscheidt and Pearson, 1989; Valdés-Gómez et al., 2011), grape phenology and disease etiology (Kennelly et al., 2005; Molitor and Berkelmann-Loehnertz, 2011), and timing of spray applications (Nita et al., 2006b, 2008)] could also help further improve disease and pest management in organic systems.

\section{Literature cited}

Bunea, C., N. Pop, A.C. Babeş, C. Matea, F.V. Dulf, and A. Bunea. 2012. Carotenoids, total polyphenols and antioxidant activity of grapes (Vitis vinifera) cultivated in organic and conventional systems. Chem. Cent. J. 6:66, doi: 10.1186/1752153X-6-66.

Conway, J. 2018. Organic wine sales in the United States from 2007 to 2016. Statista. 4 May 2018. <https://www. statista.com/statistics/857204/organicwine-sales-in-the-us $/>$.

Conway, J. 2019. Number of wineries in the United States in 2019 , by state. Statista. 10 Feb. 2020. <https://www. statista.com/statistics/259365/numberof-wineries-in-the-us-by-state $/>$.

D'Amico, M., G. Di Vita, and L. Monaco. 2016. Exploring environmental consciousness and consumer preferences for organic wines without sulfites. J. Clean. Prod. 120:64-71, doi: 10.1016/j.jclepro.2016.02.014

Desta, A. 2008. Conventional versus environmentally-sensitive wines: The status of wine production strategies in California north coast counties. J. Business Pub. Affairs 2:1-17.

Ellis, M.K. and M. Nita. 2004. Organic small fruit disease management guidelines. Integrated management of grape diseases. 10 Jan. 2019. <https://cdn. ymaws.com/www.mngrapes.org/ resource/resmgr/Files/OSU-OrganicGrape-Diseases.pdf>.

Erincik, O., L.V. Madden, D.C. Ferree, and M.A. Ellis. 2003. Temperature and wetness-duration requirements for grape leaf and cane infection by Phomopsis viticola. Plant Dis. 87:832-840, doi: 10.1094/ PDIS.2003.87.7.832.

Esteban, M.A., M.J. Villanueva, and J.R. Lissarrague. 1999. Effect of irrigation on changes in berry composition of Tempranillo during maturation. Sugars, organic acids, and mineral elements. Amer. J. Enol. Viticult. 50:418-434.

Kennelly, M.M., D.M. Gadoury, W.F. Wilcox, P.A. Magarey, and R.C. Reem. 2005. Seasonal development of ontogenic resistance to downy mildew in grape berries and rachises. Phytopathology 95:14451452, doi: 10.1094/PHYTO-95-1445.

Madden, L.V., M.A. Ellis, N. Lalancette, G. Hughes, and L.L. Wilson. 2000. Evaluation of a disease warning system for downy mildew of grapes. Plant Dis. 84:549-554, doi: 10.1094/PDIS.2000.84.5.549.

Molitor, D. and B. Berkelmann-Loehnertz. 2011. Simulating the susceptibility of clus- 
ters to grape black rot infections depending on their phenological development. Crop Prot. 30:1649-1654, doi: 10.1016/ j.cropro.2011.07.020.

National Centers for Environmental Information. 2020. Richmond international airport (GHCND:USW00013740). 8 Dec. 2020. <https://www.ncdc.noaa.gov/cdoweb/datasets $>$.

Nita, M., M.A. Ellis, and L.V. Madden. 2008. Variation in disease incidence of phomopsis cane and leaf spot of grape in commercial vineyards in Ohio. Plant Dis. 92:1053-1061, doi: 10.1094/PDIS-92-71053.

Nita, M., M.A. Ellis, L.L. Wilson, and L.V. Madden. 2006a. Evaluation of a disease early warning system for phomopsis cane and leaf spot of grape: A field study. Plant Dis. 90:1239-1246, doi: 10.1094/PD-90-1239.

Nita, M., M.A. Ellis, L.L. Wilson, and L.V. Madden. 2006b. Effects of application of fungicide during the dormant period on phomopsis cane and leaf spot of grape disease intensity and inoculum production. Plant Dis. 90:1195-1200, doi: 10.1094/PD-90-1195.

Núñez-Delicado, E., A. Sánchez-Ferrer, F.F. García-Carmona, and J.M. LópezNicolás. 2006. Effect of organic farming practices on the level of latent polyphenol oxidase in grapes. J. Food Sci. 70:C74-C78, doi: 101111/j.1365-2621.2005.tb09024.x.

Organic Materials Review Institute. 2020. OMRI product lists. 12 Oct. 2020. <https://www.omri.org/omri-lists>.

Ough, C.S. and V.L. Singleton. 1968. Wine quality prediction from juice Brix/ acid ratio and associated compositional changes for 'White Riesling' and 'Cabernet Sauvignon'. Amer. J. Enol. Viticult. 19:129-138.
Pscheidt, J.W. and R.C. Pearson. 1989. Effect of grapevine training systems and pruning practices on occurrence of phomopsis cane and leaf spot. Plant Dis. 73:825-828, doi: 10.1094/PD-73-0825.

Quality Certification Services. 2013. Entity \# $1304 \mathrm{G}$, Hambsch family vineyard of North Garden, VA. 15 Dec. 2020. <https://www. qcsinfo.org/organic/>.

Reeve, J.R., L. Carpenter-Boggs, J.P. Reganold, A.L. York, G. McGourty, and P.L. McCloskey. 2005. Soil and winegrape quality in biodynamically and organically managed vineyards. Amer. J. Enol. Viticult. 56:367-376.

Reisch, B., S. Luce, and A.K. Mansfield. 2013. Recent releases and numbered selections from the Geneva grape breeding program. 14 Aug. 2020. <http://www. hort.cornell.edu/reisch/grapegenetics / cultivars.html>.

Schilder, A.C. 2008. Report to the North Central pest management center. Evaluation of reduced-risk and biological fungicides for control of diseases in grapes and blueberries. Ctr. Integrated Plant Syst., Michigan State Univ., East Lansing.

Schilder, A.M.C., J.M. Gillett, R.W. Sysak, and J.C. Wise. 2002. Evaluation of environmentally friendly products for control of fungal diseases of grapes, p. 163-167. In: B. Markus (ed.). Proc. 10th Intl. Conf. Cultivation Technique and Phytopathological Problems in Organic Fruit-Growing and Viticulture. 4-7 Feb. 2002, Weinsberg, Germany. 23 Dec. 2020. <https://orgprints. org/14620/1/schilder_163.pdf>.

U.S. Department of Agriculture, National Agricultural Statistics Service. 2017. Certified organic survey 2016: Summary. 24 Jan. 2020. <https://www.nass.usda. gov/Publications/Todays_Reports/ reports/census17.pdf>.
U.S. Department of Agriculture, National Agricultural Statistics Service. 2019. Virginia agricultural statistics: 2019 Annual bulletin. 20 Aug. 2020. <https://www. nass.usda.gov/Statistics_by_State/ Virginia/Publications / Annual_ Statistical_Bulletin/index.php $>$.

Valdés-Gómez, H., C. Gary, P. Cartolaro, M. Lolas-Caneo, and A. Calonnec. 2011. Powdery mildew development is positively influenced by grapevine vegetative growth induced by different soil management strategies. Crop Prot. 30:1168-1177, doi: 101016/j.cropro.2011.05.014.

Vian, M.A., V. Tomao, P.O. Coulomb, J.M. Lacombe, and O. Dangles. 2006. Comparison of the anthocyanin composition during ripening of Syrah grapes grown using organic or conventional agricultural practices. J. Agr. Food Chem. 54:5230-5235, doi: $10.1021 /$ jf0531609.

Virginia Vineyards Association. 2008. VA wine board 2008 research priorities questionnaire. 4 Nov. 2020. <https:// www.virginiawine.org/industry/ virginia-wine-board $>$.

Vrček, I.V., M. Bojić, I. Žuntar, G. Mendaš, and M. Medić-Šarić. 2011. Phenol content, antioxidant activity and metal composition of Croatian wines deriving from organically and conventionally grown grapes. Food Chem. 124:354-361, doi: 101016/j.foodchem.2010.05.118.

Willer, H. and J. Lernoud (eds.). 2019. The world of organic agriculture. Statistics and emerging trends 2019. 5 Oct. 2020. <https://shop.fibl.org/CHen/ 2020-organic-world-2019.html\#>.

Wolf, T.K. 2008. Wine grape production guide for eastern North America. 6 July 2020. <https://hdl.handle.net/1813/ 67189>. 